\title{
STAND STRUCTURE DIVERSITY IN Pinus Sylvestris L. WOODLANDS IN THE CENTRAL MOUNTAIN RANGE (SPAIN)
}

\author{
Ignacio Barbeito ${ }^{1}$, Fernando Montes $^{2}$, Isabel Cañellas ${ }^{3}$
}

\section{SUMMARY}

The purpose of this study was to assess the structure of Scots Pine (Pinus sylvestris L.) stands at different developmental stages through the altitudinal range of its distribution area in Valsaín forest, located in the Central Mountain Range of Spain.

Trees were mapped and their diameter, height and crown height measured in 0.5 ha plots. Gadow's differentiation, Shannon index and structure complexity index (SCl) were used in order to describe the vertical structure.

The highest vertical diversity was found in the plots located near the upper limit of the altitudinal range, where high mountain shrubs replace the Scots Pine forest, and near the lower limit where the Pyrenean Oak (Quercus pyrenaica Willd.) appears mixed with the Scots Pine, as well as during the regeneration stage.

The results found may support managers an objective analysis in order to include diversity in decision-making.

Keywords: Pinus sylvestris, stand structure, altitudinal levels.

\section{RESUMEN}

El propósito de este trabajo es evaluar la estructura de rodales de Pinus sylvestris L. en diferentes etapas de desarrollo a través del rango altitudinal de su área de distribución, en el bosque Valsain, ubicado en la Cordillera Central de España.

Los árboles fueron cartografiados y sus diámetros, alturas y alturas de copa fueron medidas en parcelas de 0,5 ha. Para describir la estructura vertical se emplearon la diferenciación de Gadow, el índice de Shannon y el índice de complejidad de estructura.

La más alta diversidad vertical fue encontrada en las parcelas ubicadas cerca del límite superior del rango altitudinal, donde arbustos de alta montaña reemplazan el bosque de esta especie, y cerca del límite inferior, donde Quercus pyrenaica Willd. se mezcla con la especie, como asimismo durante la etapa de regeneración.

Los resultados obtenidos pueden ayudar a los silvicultores con un análisis objetivo para incluir la diversidad en la toma de decisiones.

Palabras clave: Pinus sylvestris, estructura de rodal, niveles altitudinales.

1 CIFOR-INIA, Spain, barbeito@inia.es

2 CIFOR-INIA, Spain, canellas@inia.es

3 ETSI Montes, UPM, Spain, fmontes@inia.es 


\section{INTRODUCTION}

The vertical structure of forest ecosystems depends on intra and inter specific competition, site conditions, shade tolerance and disturbance regimes, and is widely acknowledged to characterize forest biodiversity (MacArthur and MacArthur, 1961, North et al., 1999). It offers the advantage of being easily measured in the field and at the same time it provides a large amount of valuable information.

One of the most widely used methods to assess the vertical structure diversity consists on calculating the Shannon index (Shannon, 1949) with the foliage distribution in vertical strata. This index is denominated foliage height diversity index or FHD (MacArthur \& MacArthur, 1961). The FHD requires a specific sampling method to asses the vertical arrangement of the vegetal layers (Ferris-Kaan et al.,1998), and it is not straight forward to apply when there are not well defined vegetal layers. Some authors have used Shannon's diversity index by diameter classes (Buongiorno et al., 1994; Staudhammer \& LeMay, 2001). Recently, some new methods have been developed to characterize the pattern of the vertical structure. Gadow's differentiation index (Gadow, 1993; Gadow \& Hui, 1999) extends the nearest neighbor methods to the vertical structure analysis. Other index based on the distance between the top of neighbour trees is the structure complexity index (SCl) proposed by Zenner and Hibbs (2000).

Stand structure has been largely studied in managed forests recently but few studies have dealt with this issue in Mediterranean forests. This study aims to compare how different methods to assess height heterogeneity capture the vertical structure in Scots pine forest to obtain quantitative measures that can be used to evaluate the vertical structure across the stand life and at different ecological conditions.

\section{MATERIAL AND METHODS}

\section{Data Collection}

The data of this study derives from Pinar de Valsaín, a managed Scots Pine forest located in the North facing slopes of the Sierra de Guadarrama in the Central Mountain Range in Spain. The altitude ranges between 1200 and $2200 \mathrm{~m}$, with mean annual temperature around $9^{\circ} \mathrm{C}$ and over $730 \mathrm{~mm}$ of annual rainfall. Group shelterwood system is followed in this forest, allowing regeneration to take place naturally in a 40 years period.

Eight rectangular 0.5 ha plots were installed through the altitudinal growth range of Scots Pine. Six of them were established including all the current age classes in the forest, from 1-20 years (plot V1) to 101-120 years (plot V6), where rotation length is 120 years. The other two plots were placed at uneven stands near the lower and upper limits of Scots Pine spectrum. Plot V7 was located at 1300 m where Scots Pine appears mixed with Pyrenean Oak (Quercus pyrenaica) and plot V8 was situated at $1800 \mathrm{~m}$ where Scots Pine appears mixed with alpine shrubs (Juniperus communis ssp nana).

Diameter at breast height $(\mathrm{dbh})$ and height $(\mathrm{H})$ were measured for all trees. Stems higher than $1.30 \mathrm{~m}$ were located through their xy coordinates while saplings below $1.30 \mathrm{~m}$ in height were recorded in a $2 \times 2 \mathrm{~m}^{2}$ grid situated over the plots. 
Table 1

STAND LEVEL VARIABLES IN THE EXPERIMENTAL PLOTS

\begin{tabular}{|c|c|c|c|c|c|c|c|c|c|}
\hline \multirow[b]{2}{*}{ Plot } & \multirow[b]{2}{*}{ Plot size } & Age & $\mathrm{N}$ & $\mathrm{N}$ & dbh & dbh & \multirow[b]{2}{*}{ BA } & $\mathrm{H}$ & H \\
\hline & & class & $\geq 10 \mathrm{~cm}$ & $<10 \mathrm{~cm}$ & $\geq 10 \mathrm{~cm}$ & $<10 \mathrm{~cm}$ & & $\geq 10 \mathrm{~cm}$ & $<10 \mathrm{~cm}$ \\
\hline V1 & $100 \times 50$ & $1-20$ & 584 & 7468 & 20.2 & 2.4 & 34.4 & 13.6 & 3.1 \\
\hline V2 & $85 \times 58.8$ & $20-40$ & 1668 & 936 & 16 & 4.9 & 41 & 14.3 & 6.3 \\
\hline V3 & $100 \times 50$ & $40-60$ & 1322 & 0 & 20.5 & - & 48.5 & 16.4 & - \\
\hline V4 & $100 \times 50$ & $60-80$ & 686 & 0 & 30.5 & - & 53.3 & 23.5 & - \\
\hline V5 & $70.7 \times 70.7$ & $80-100$ & 550 & 0 & 34.6 & - & 54 & 22.1 & - \\
\hline V6 & $100 \times 50$ & $100-120$ & 334 & 318 & 38.3 & 1.5 & 41.4 & 24 & 2.1 \\
\hline V7 & $70.7 \times 70.7$ & Uneven & 608 & 964 & 18.8 & 1.6 & 25.2 & 11.5 & 2.4 \\
\hline V8 & $100 \times 50$ & Uneven & 578 & 244 & 19.9 & 3.6 & 22.7 & 10 & 3.3 \\
\hline
\end{tabular}

(Extent 0.5 ha) in Valsaín forest (V1, V2, V3, V4, V5, V6, V7 and V8): Plot size in $\mathrm{m}^{2}$; Age class (years); $\mathrm{N} 10 \mathrm{~cm}$ and N $<10 \mathrm{~cm}$, tree number per ha with $\mathrm{dbh} 10 \mathrm{~cm}$ and $\mathrm{dbh}<10 \mathrm{~cm}$ respectively; $\mathrm{dbh} 10 \mathrm{~cm}$ and $\mathrm{dbh}<10 \mathrm{~cm}$, mean diameter at breast height $(\mathrm{cm})$ of tree with $\mathrm{dbh} 10$ and $\mathrm{dbh}<10 \mathrm{~cm}$ respectively; $\mathrm{BA}$, basal area $\left(\mathrm{m}^{2} / \mathrm{ha}\right) ; \mathrm{H}>10 \mathrm{~cm}$ and $\mathrm{H}<10$ $\mathrm{cm}$, mean height $(\mathrm{m})$ of tree with $\mathrm{dbh} 10$ and $\mathrm{dbh}<10 \mathrm{~cm}$ respectively.

\section{Vertical Structure Analysis}

\section{- Distance independent indices}

Shannon's index (Shannon,1949) was used to estimate the height diversity using it with basal area by height classes:

$$
F H D^{\prime}=-\sum_{i=1}^{s} p_{i} \ln p_{i} \quad \text { with: } \quad p_{i}=\frac{\sum_{j=1}^{N} G j i}{\sum_{i=1}^{s} \sum_{j} G j i}
$$

Where: $s$ is the number of height classes at $5 \mathrm{~m}$ intervals (being the lower limit of the first class 0 ) in the plot and $p i$ is the ratio between the basal area of the ith tree and the total basal area. variance:

Height distribution's diversity was also measured using the structure index based on the

$$
S T V I=\sum_{i=1}^{n} \sum_{j=1}^{n} p_{i} p_{j}\left(H_{i}-H\right)^{2}
$$

Where: $n$ is the number of trees in the sample, $p_{i}$ is the ratio between the basal area of the $i^{\text {th }}$ tree and the total basal area, $H_{i}$ is the height of tree $i^{\text {th }}$ tree and $n / N$ is the sampled fraction.

This structure index based on the variance proposed by Staudhammer and LeMay (2001) was somewhat more complex, because it was standardised to be 0.5 when the distribution is uniform 
over half of the total range and when the distribution is bimodal with half the values uniformly distributed over the lower quartile and the other half uniformly distributed over the upper quartile, and was also constrained to equal to 0.1 for a distribution with half of the values equal to the lowest and half equal to the highest (maximum variance).

\section{- Distance dependent indices}

Gadow's differentiation index $(\mathrm{DH} n)$ has been used to measure small-scale variability in the height size distribution (Gadow 1993, Gadow and Hui 1999). The $\mathrm{DH} n$ is given by:

$$
D H n=\frac{1}{N} \sum_{i=1}^{n} D H n_{i} \quad \text { with: } \quad D H n i=\frac{1}{n} \sum_{j=1}^{n}\left(1-\frac{x \min }{x \max }\right)_{j}
$$

Where: $\mathrm{DHn}$ is the mean differentiation calculated for $\mathrm{n}$ neighbours, $N$ the number of trees per plot and DHni the differentiation index for tree $i$ calculated with $n$ neighbours, and where xmin and xmax are the smallest and the largest height among tree $i$ and its $n$ neighbours. Values close to 0 indicate that the neighbours are of a very similar size, whereas values close to 1 reflect high differentiation. In this study three neighbours were included $(n=3)$, this being the usual practice (Füldner 1995).

Another index used to characterize the neighbourhood height differentiation is the structure complexity index (SCl) developed by Zenner and Hibbs (2000). This index integrates tree height and horizontal spatial pattern. Points marking the top of each three neighbouring trees are connected, constructing a 3- dimensional continuous tessellation of non-overlapping triangles. This triangular irregular network satisfies the Delaunay criterion (Fraser and van den Driessche, 1971) (i.e., a circle drawn through the three nodes of a triangle contains no other point, the triangles are as equi-angular as possible and the triangulation is independent of the order in which the points are processed).

$$
S C I=\frac{\sum_{i=1}^{N} \frac{1}{2}\left|a_{i} \times b_{i}\right|}{A_{T}}
$$

Where: $A$ t is the sum of the projected areas of the triangles, $i=1 \ldots \mathrm{N}$ is the number of triangles in the test plot, and $\frac{1}{2}\left|a_{i} \times b_{i}\right|$ represents the surface area in 3-dimensions connecting $x, y$ and $z$ coordinates of trees. $\mathrm{SCl}$ is at its minimum when it is equal to one, when all the trees in the stand have the same height.

\section{RESULTS AND DISCUSSION}

Table 2 shows the evolution of the different vertical indices obtained for the experimental plots in Valsaín. The vertical differentiation shows a decreasing trend over the life of the stand with a slight increase in the oldest plot. The values for all the analysed vertical structure diversity 
indices were greater for the stages from regeneration to the first thinning under low intensive silviculture (V1) and in the plots located at the upper (V8) and lower limits (V7) of the distribution limits of Scots pine.

Table 2.

VERTICAL STRUCTURE INDICES IN THE EXPERIMENTAL PLOTS IN VALSAÍN FOREST

\begin{tabular}{|c|c|c|c|c|}
\hline Plot & FHD & STVI & DH3 & SCI \\
\hline V1 & 1.55 & 74.32 & 0.19 & 2.89 \\
\hline V2 & 1.21 & 17.14 & 0.13 & 2.05 \\
\hline V3 & 0.93 & 8.25 & 0.12 & 1.80 \\
\hline V4 & 0.73 & 9.94 & 0.07 & 1.42 \\
\hline V5 & 0.59 & 7.00 & 0.07 & 1.30 \\
\hline V6 & 0.89 & 8.19 & 0.07 & 1.25 \\
\hline V7 & 1.34 & 196.05 & 0.17 & 1.79 \\
\hline V8 & 1.06 & 119.11 & 0.25 & 1.87 \\
\hline
\end{tabular}

H', Shannon's index; STVI: structure index based on the variance;

$\mathrm{DH} 3$, Gadow's index for height and 3 neighbours; $\mathrm{SCl}$, structure complexity index.

A decreasing trend of Shannon index was clear over the life of the stand, with a slight increase in the oldest plot. The behaviour of the STVI index over the life of the stand is even more evident. The vertical differentiation $(\mathrm{DH} 3)$ shows a decreasing trend over the life of the stand, and asymptotizes when the stand reaches the stem exclusion stage. SCl showed the same general trend as DH3. The plots located at the upper and lower limits of the distribution area of the species showed high values for all the analysed vertical structure diversity (Table 2).

The vertical structure diversity is commonly estimated by using the foliage height diversity index (FHD), which consists of applying the Shannon index to the height distribution of foliage. This index has been largely used in ecological studies and has been proved to be a good indicator of structure complexity of the forest (Kuuluvainen et al.,1996). The relative frequency (estimated through the number of contacts within each layer) can be substituted in the Shannon index for the proportion of basal area corresponding to each height class (Staudhammer \& LeMay, 2001). The basal area is approximately proportional to the space occupied by the tree crown. However, this index is dependant on the class size width and there is no agreement in literature about what class width or how many classes should be used, and of how sensitive the index is to the change of class width (Ferris-Kaan et al., 1998; Varga et al., 2005).

The use of indices based on the variance, such as STVI (Staudhammer \& LeMay, 2001), has the advantage that their value does not depend on the artificial set of the class boundaries. Nevertheless, diversity indices based on the variance behave quite different than those derived from the Shannon's index, because the variance is maximum when the distribution is binomial with half of the trees in the lower class and the other in the upper class, whereas the diversity reaches a maximum when all the classes are evenly represented (Magurran, 1988). Height diversity must be referred to the scale of the study to be used in analysis of vegetation dynamics 
or comparative studies.

The distance dependant indices of vertical structure analysed give a picture of the height variability at micro-scale, i.e., a tree and its neighbours. Gadow's differentiation index was used to describe patterns at microstructure level, because it operates only for the immediate neighbourhood of each tree, and it assigns an index value to each tree of the stand. The differentiation index has been used for structural characterization of forests (Aguirre et al., 2003), but as it quantifies the variability of height between neighbor trees, its utilization to link structural changes, silviculture applied and competition may be promising (Montes et al., 2004). Nevertheless, the neighborhood scale assessment gives little information about the stand structure and many processes that take place at larger scales. The $\mathrm{SCl}$ index proposed by Zenner and Hibbs (2000) integrates the horizontal spatial pattern and tree height, giving us a complexity measure of the 3-dimensional structure, and additional information about heights distribution in our stands, but is mainly influenced by the micro-scale vertical structure.

These height diversity indices give a picture of height variability at micro-scale and can be used to compare or monitor height structure complexity at a determined scale, although the height distribution must be analysed to avoid misinterpretations of the results. This study showed that very different vertical structures can result in similar values for height diversity indices. The calculation of the distant independence indices at different scales, dividing the plot into smaller plots may show how height diversity varies with the size of the plot, and could therefore allow us to see the trend at larger scales and to study the strength of the relationship between horizontal pattern and vertical structure.

\section{ACKNOWLEDGMENTS}

The authors wish to thank Javier Donés and Juan Carlos Martín for supplying his invaluable knowledge of the forest and Angel Bachiller, and Estrella Viscasillas their help in the field work. This study has been founded by the projects AGL2000-1545, AGL2004-07094. CO2.01/FOR and AGL2004-01941/FOR of Spanish Ministry of Education and Science.

\section{REFERENCES}

Aguirre, O., Hui, G., Gadow, K. v. y Jiménez, J., 2003. An analysis of spatial forest structure using neighbourhood-based variables. Forest Ecology and Mangement, 183: 137-145.

Boungiorno, J., Dahir, S., Lu, HC., and Lin, CR., 1994. Tree size diversity and economic returns in uneved-aged forest stands. Forest Science 40: 83-103.

Ferris-Kaan, R., Peace, A.J.\& Humphrey, J.W., 1998. Assesing structural diversity in managed forests. Kluwer Academic publishers, Dordrecht.

Fraser, A.R. and van den Driessche, P., 1971. Triangles, density, and pattern in plant point populations. In Proc. 3rd Conf. Advisory Group of Forest Statisticians, Int. Union. For Res. Organ. Inst. Nat. Rech. Agric., Jout-en-Josas, France, pp. 277-286.

Füldner, K., 1995. Zur Strukturbeschreibung in Mischbeständen. Forstarchiv 66: 235-240. 
Gadow, K.V., 1993. Zur Bestandesbeschreibung in der Forsteinrichtung. Forst und Holz 21: 601-606.

Gadow, K.V. and Hui, G., 1999. Modelling Forest Development. Kluwer Academic Publishers.

Kuuluvainen,T., Penttinen,A., Leionen,L. \& Nygren, M.,1996. Statistical opportunities for comparing stand structural heterogeneity in managed and primeval forests: an example from boreal Spruce forest in southern Finland. Silva Fennica, 30: 315-328.

MacArthur, R. M. and Mac Arthur, J. W., 1961. On bird species diversity. Ecology 42:594598.

Magurran, A. E., 1988. Ecological diversity and its measurement. Princeton University Press, Princeton, N.J.

Montes, F., Cañellas, I., Rio, M.D., Calama, R. \& Montero, G., 2004. The effects of thinning on the structural diversity of coppice forests. Annals of Forest Science, 61:771-779.

North, M. P., Franklin, J. F., Carey, A. B., Forsman, E. D. and Hamer, T., 1999. Forest stand structure of the northern spotted owl's foraging habitat. Forest Science 45: 520-527

Shannon, C., 1949. The mathematical theory of communication. Eds. C. E. Shannon y W. Weaver. The mathematical Theory of Comunication. University of Illinois Press. Urbana.

Staudhammer, C. L. \& Le May, V.M., 2001. Introduction and evaluation of possible indices of stand structural diversity. Canadian Journal of Forest Research, 31:1105-1115.

Varga, P., Chen, H. Y. H. \& Klinka, K., 2005. Tree-size diversity between single- and mixedspecies stands in three forest types in western Canada. Canadian Journal of Forest Research, 35: 593-601

Zenner. E \& Hibbs, D., 2000. A new method for modelling the heterogeneity of a forest structure. Forest ecology and management, 129: 75-87. 
